\title{
Pola Pemberian Antimikroba pada Pasien Sepsis di RSUP Prof. Dr. R. D. Kandou Manado Periode Januari - Juni 2019
}

\author{
${ }^{1}$ Reinhard C. Taroreh \\ ${ }^{2}$ Harold F. Tambajong \\ ${ }^{3}$ Diana Ch. Lalenoh
}

${ }^{1}$ Program Studi Pendidikan Dokter Fakultas Kedokteran Universitas Sam Ratulangi Maando
${ }^{2}$ Bagian Anestesiologi dan Terapi Intensif Fakultas Kedokteran
Universitas Sam Ratulangi Manado
Email: reinchalvien@gmail.com

\begin{abstract}
Sepsis is defined as organ dysfunction that threatens life due to disregulated response of vulnerable host to the infection agent. Antimicrobial therapy is one of the main therapies in the management of septic cases. Survival sepsis campaign guidelines in 2016 recommended antimicrobial administration in one hour after being diagnosed as sepsis. This study was aimed to determine the pattern of antimicrobial administration among septic patients in the Intensive Care Unit of RSUP Prof. Dr. R. D. Kandou Manado. This was an observational analytical study with a cross-sectional design. Samples were intensive care unit patients of RSUP Prof. Dr. R. D. Kandou Manado diagnosed as sepsis and its classification obtained from the Medical Record Installation data for the period of January to June 2019. The results showed a total of 35 septic patients consisting of 16 females (45.7\%) and 19 males $(54.3 \%)$. The time of antimicrobial administration $\leq 1$ hour was found in 21 cases $(60 \%)$. The most frequent antimicrobial administered was ceftriaxone in 13 cases $(37.1 \%)$. The mortality rate after $>48$ hours was 13 cases $(59 \%)$. In conclusion, most antimicrobial administration was in 1 hour after being diagnosed as sepsis and ceftriaxone was the most frequent antimicrobial given. Mortality rate after administration of antimicrobial was still high.
\end{abstract}

Keywords: sepsis, ICU, antimicrobial, mortality rate

\begin{abstract}
Abstrak: Sepsis didefinisikan sebagai disfungsi organ yang mengancam nyawa akibat disregulasi respon penjamu terhadap infeksi. Terapi antimikroba merupakan salah satu terapi utama dalam penatalaksanaan kasus sepsis. Pedoman Survival Sepsis Campaign tahun 2016 menyatakan pemberian antimikroba yang direkomendasikan ialah satu jam setelah terdiagnosiss sepsis. Penelitian ini bertujuan untuk mengetahui pola pemberian antimikroba pada pasien sepsis di Intensive Care Unit RSUP Prof. Dr. R. D. Kandou Manado. Jenis penelitian ialah analitik observasional dengan desain potong lintang. Sampel penelitian ialah pasien ICU Prof. Dr. R. D. Kandou Manado dengan diagnosis sepsis dan klasifikasinya, diperoleh dari data Bagian Instalasi Rekam Medik periode Januari-Juni 2019. Hasil penelitian mendapatkan total 35 pasien dengan diagnosis sepsis, terdiri dari 16 orang perempuan $(45,7 \%)$ dan 19 orang laki-laki $(54,3 \%)$. Waktu pemberian antimikroba $\leq 1$ jam pada sebanyak 21 kasus (60\%). Penggunaan antimikroba yang sering diberikan ialah ceftriaxone pada 13 kasus $(37,1 \%)$. Angka kematian setelah $>48$ jam sebanyak 13 kasus (59\%). Simpulan penelitian ini ialah sebagian besar pemberian antimikroba 1 jam setelah didiagnosis sepsis dengan ceftriaxone sebagai antimikroba yang paling sering diberikan. Angka kematian pasca pemberian antimikroba masih tinggi.
\end{abstract}

Kata kunci: sepsis, ICU, antimikroba, angka kematian 
Sepsis didefinisikan sebagai disfungsi organ yang mengancam nyawa akibat disregulasi respon penjamu terhadap infeksi. Definisi baru ini menekankan keunggulan respon pejamu non-homeostatik terhadap infeksi, potensi kematian yang dipertimbangkan melebihi infeksi langsung, dan kebutuhan akan diagnosis segera pada tingkat disfungsi organ ketika pertama kali dicurigai sebagai sepsis. Sepsis memengaruhi jutaan orang diseluruh dunia dan setiap tahunnya sepsis menjadi penyebab utama kematian pada pasien dengan sakit kritis. ${ }^{1}$ Penelitian yang dilakukan oleh Vincent et $\mathrm{al}^{2}$ mendapatkan pasien dengan sepsis sebanyak 7.087 dari 13.796 pasien yang dirawat di rumah sakit; $71 \%$ menerima terapi antimikroba dan $16 \%$ menerima terapi antifungal dengan angka kematian di Intensive Care Unit (ICU) mencapai 33,3\% dan $46,8 \%$ penyebab sepsis ialah bakteri Gram positif. ${ }^{2}$

Terapi antimikroba merupakan salah satu terapi utama dalam penatalaksanaan pada kasus sepsis. ${ }^{3}$ Pedoman dari Survival Sepsis Campaign (SSC) tahun 2016 menyatakan pemberian antimikroba direkomendasikan satu jam setelah terdiagnosis sepsis. Sterling et $\mathrm{al}^{4}$ melaporkan tidak adanya manfaat yang bermakna pemberian antimikroba dalam 1 jam setelah terdiagnosis sepsis dengan 11.017 pasien yang dilibatkan dalam penelitiannya. Pada 3.335 pasien yang diberikan terapi 1 jam setelah terdiagnosis sepsis, 1.174 di antaranya meninggal dunia. Pemberian antimikroba juga harus diperhatikan terkait dengan jenis dan dosis yang berikan. Pada penelitian yang dilakukan Dewi et $\mathrm{al}^{4}$ pada 60 sampel penelitian, 33,3\% mengalami kesalahan pemberian jenis antimikroba dan $51,7 \%$ mengalami kesalahan dosis dengan angka kematian mencapai 68,3\%.

Berdasarkan latar belakang ini maka penelitian ini dilakukan untuk mengetahui pola pemberian antimikroba pada pasien sepsis di Intensive Care Unit (ICU) RSUP Prof. Dr. R. D. Kandou Manado.

\section{METODE PENELITIAN}

Penelitian ini dilakukan di Intensive
Care Unit RSUP Prof. Dr. R. D. Kandou Manado. Jenis penelitian ialah deskriptif observasional. Populasi penelitian ialah semua pasien yang terdiagnosis sepsis di ruangan ICU RSUP Prof. Dr. R. D. Kandou Manado periode Januari-Juni 2019. Pasien yang diambil sebagai sampel ialah semua pasien yang memenuhi kriteria inklusi. Data penelitian diambil dari data rekam medis pasien di ICU periode Janurari - Juni 2019. Variabel penelitian ini ialah sepsis, ICU, rerata pemberian antimikroba, jenis antimikroba yang diberikan, dan angka kematian.

\section{HASIL PENELITIAN}

Berdasarkan data yang diperoleh di ruangan ICU RSUP Prof. Dr. R. D. Kandou Manado periode Januari-Juni 2019, didapatkan 42 pasien dengan diagnosis sepsis; 35 kasus mempunyai rekam medik yang sesuai dengan kriteria inklusi. Tujuh rekam medik tidak memenuhi kriteria inklusi karena kehilangan data di sistem manajemen rumah sakit. Dari 35 kasus sepsis, terdapat 16 orang perempuan dan 19 orang laki-laki. Tabel 1 memperlihatkan distribusi pasien sepsis yang bervariasi dari usia $\leq 17$ tahun $\mathrm{s} / \mathrm{d} \geq 74$ tahun dengan usia terbanyak pada 45-59 tahun (42,8\%).

Tabel 1. Distribusi usia pasien sepsis

\begin{tabular}{ccc}
\hline $\begin{array}{c}\text { Usia } \\
\text { (tahun) }\end{array}$ & $\begin{array}{c}\text { Jumlah } \\
\text { (orang) }\end{array}$ & $\%$ \\
\hline$\leq 17$ & 1 & 2,9 \\
$18-29$ & 1 & 2,9 \\
$30-44$ & 6 & 17,1 \\
$45-59$ & 15 & 42,8 \\
$60-73$ & 8 & 22,9 \\
$\geq 74$ & 4 & 11,4 \\
Total & 35 & 100 \\
\hline
\end{tabular}

Tabel 2 memperlihatkan waktu pemberian antimikroba yang terbanyak setelah diagnosis sepsis ditegakkan ialah $\leq 1$ jam, sebesar $60 \%$.

Tabel 3 memperlihatkan bahwa terdapat 8 jenis antimikroba yang sering diberikan; yang terbanyak ialah golongan ceftriaxone, sebesar $37,1 \%$. 
Tabel 4 memperlihatkan bahwa angka kematian pasca pemberian antimikroba yang tertinggi ialah setelah 48 jam, sebesar $59 \%$.

Tabel 2. Waktu pemberian antimikroba

\begin{tabular}{ccc}
\hline $\begin{array}{c}\text { Waktu } \\
\text { pemberian }\end{array}$ & $\begin{array}{c}\text { Jumlah } \\
\text { kasus }\end{array}$ & $\%$ \\
\hline$\leq 1$ jam & 21 & 60 \\
$\leq 2-12$ jam & 12 & 34,3 \\
$>12-24$ jam & 2 & 5,7 \\
Total & 35 & 100 \\
\hline
\end{tabular}

Tabel 3. Jenis antimikroba yang sering diberikan

\begin{tabular}{ccc}
\hline $\begin{array}{c}\text { Jenis } \\
\text { antimikroba }\end{array}$ & $\begin{array}{c}\text { Jumlah } \\
\text { Kasus }\end{array}$ & $\%$ \\
\hline Ceftriaxone & 13 & 37,1 \\
Levofloxacin & 9 & 26 \\
Meropenem & 5 & 14,3 \\
Ciprofloxacin & 3 & 8,5 \\
Moxifloxacin & 2 & 5,7 \\
Cefepime & 1 & 2,8 \\
Ampicilin & 1 & 2,8 \\
Vancomicin & 1 & 2,8 \\
Total & 35 & 100 \\
\hline
\end{tabular}

Tabel 4. Angka kematian pasca pemberian antimikroba

\begin{tabular}{ccc}
\hline $\begin{array}{c}\text { Waktu } \\
\text { kematian }\end{array}$ & $\begin{array}{c}\text { Jumlah } \\
\text { kasus }\end{array}$ & $\%$ \\
\hline$\leq 12-24$ jam & 8 & 36,4 \\
$\geq 24-48$ jam & 1 & 4,6 \\
$>48$ jam & 13 & 59 \\
Total & 22 & 100 \\
\hline
\end{tabular}

\section{BAHASAN}

Berdasarkan pedoman SSC tahun 2016, durasi pemberian antimikroba pada pasien dengan diagnosis sepsis ialah 1 jam setelah terdiagnosis. ${ }^{3}$ Pedoman SSC menyatakan bahwa disamping pemberian antimikroba, dalam satu jam menurut rekomendasi ini dapat dilakukan terapi farmakologis lainnya untuk mencegah terjadinya kegagalan organ vital yang berujung pada syok septik.

Pemberian antimikroba pada pasien sepsis di ICU RSUP Prof. Dr. R. D. Kandou Manado paling banyak <1 jam setelah terdiagnosis (Tabel 2). Satu jam pemberian ini didasarkan pada pola mikroorganisme penyebab dilihat dari gejala yang ditimbulkan maupun riwayat mikroorganisme tersebut. Semakin cepat tatalaksana yang diberikan maka akan semakin bagus prognosis yang akan dihasilkan.

Sebuah studi kohort retrospektif dari 760 pasien yang dirawat dengan sepsis dan syok septik dengan penyebab bakteri Gram negatif, menunjukkan secara statistik tingkat kematian di rumah sakit yang lebih tinggi pada pasien yang tidak diberikan terapi antimikroba saat terdiagnosis. ${ }^{6}$ Pemilihan antimikroba spektrum luas yang tepat dapat menurunkan angka kematian pasien sepsis dengan pemberian yang disesuaikan dengan riwayat resistensi mikroorganisme terhadap antimikroba, manifestasi klinik, serta faktor risiko penyakit penyerta. Riwayat penyakit kronik seperti diabetes melitus, human immunodeficiency virus, atau adanya perangkat invasif medis seperti kateter vena sentral dan kandung kemih merupakan pertimbangan dalam memilih regimen antimikroba. $^{7}$

Terapi antimikroba spektrum luas digunakan pada semua kemungkinan mikroba penyebab yang harus diberikan segera untuk mengurangi dampak dari sepsis. ${ }^{8}$ Hasil penelitian ini mendapatkan bahwa ceftriaxone merupakan salah satu antimikroba yang paling sering diberikan yaitu sebanyak 37,1\% (Tabel 3). Penulis berasumsi bahwa penggunaan jenis antimikroba ini disamping hal yang telah disebutkan juga didasari dengan ketersediaan antimikroba di rumah sakit maupun kesesuaian dengan peta kuman yang terdapat di rumah sakit. Pengenalan dini akan tanda dan gejala sepsis dapat membantu dalam pemilihan regimen antimikroba yang diberikan. Hasil penelitian in selaras dengan penelitian oleh Rukmana ${ }^{9}$ terhadap pasien ICU RSUD Dr. Moewardi Surakarta Tahun 2016-2017 yang mendapatkan golongan sefalosporin yaitu ceftriaxon merupakan jenis antimikroba yang paling sering digunakan $(71,7 \%)$. 
Penggunaan antimikroba harus disesuaikan dengan mikroba yang menginfeksi dan sensitivitasnya terhadap antimikroba yang diberikan. Penilaian faktor penjamu dalam hal ini ialah manusia harus memperhatikan beberapa hal seperti status kekebalan tubuh, fungsi organ, tempat infeksi, riwayat penggunaan antimikroba, serta jika terdapat riwayat resistensi terha-dap suatu antimikroba. $^{10}$

Hasil penelitian ini mendapatkan perbedaan bermakna pada angka kematian pasien sepsis dengan angka kematian tertinggi pada rata-rata waktu $>48$ jam. Dari data yang diperoleh di ICU RSUP Prof. Dr. R. D. Kandou Manado periode penelitian ini (Janauri - Juni 2019) didapatkan 22 dari 35 pasien dinyatakan meninggal dengan angka kematian yang cukup tinggi yaitu sebesar $62,8 \%$ dimana waktu paling banyak terdapat pada $>48$ jam yaitu sebesar 59\% (Tabel 4). Hasil penelitian ini tidak jauh berbeda dengan penelitian yang dilakukan oleh Tambajong et $\mathrm{al}^{11}$ yang mendapatkan angka kematian cukup tinggi pada pasien sepsis di ruangan ICU RSUP Prof. D. R. Kandou Manado periode Desember 2014 - November 2015 yaitu mencapai $65,7 \%$.

Menurut asumsi penulis, penyakit penyerta dari pasien sepsis dapat menjadi salah satu penyebab angka kematian yang tinggi karena dalam penelitian ini ditemukan banyak riwayat penyakit penyerta yang mendasari terjadinya sepsis pada pasien di ICU. Pengambilan kultur darah yang memakan waktu cukup lama dapat menyebabkan tertundanya pemberian antimikroba mengingat kesalahan dalam pemberian antimikroba dapat berakibat fatal yang berujung pada kematian.

Pemahaman patogenesis yang mendasarinya dengan respon imunologis akan membuat diagnosis dini dan tatalaksana lebih komprehensif. ${ }^{12}$ Usia, sistem kekebalan tubuh, penyakit penyerta, riwayat resistensi antimikroba, serta kegagalan penggunaan regimen antimikroba turut memengaruhi angka kematian sepsis. ${ }^{11,13}$ Mikroba penyebab sepsis harus segera ditangani karena infeksi yang disebabkan sulit dihentikan sampai mikroba dapat dikendalikan. Ketika mikroba penyebab tidak diketahui, maka pemberian antimikroba spektrum luas harus segera dimulai. Tidak adanya data yang lengkap mengenai mikroba penyebab sepsis menyebabkan penggunaan antimikroba yang tidak terkontrol dalam penanganan sepsis. ${ }^{13}$

\section{SIMPULAN}

Berdasarkan hasil penelitian ini dapat disimpulkan bahwa sebagian besar pemberian antimikroba dilakukan 1 jam setelah diagnosis sepsis ditegakkan dengan ceftriaxone sebagai antimikroba yang paling sering diberikan. Angka kematian pasca pemberian antimikroba masih tinggi.

Bagi peneliti lanjut, disarankan untuk melakukan penelitian terhadap tatalaksana farmakologis lain yang diberikan pada pasien sepsis serta melihat angka harapan hidup pasca pemberian tatalaksana tersebut.

\section{DAFTAR PUSTAKA}

1. Singer M, Deutschman CS, Seymour CW, Shankar-Hari M, Annanae D, Bauer M, et al. The Third International Consensus Definition for Sepsis and Septic Shock (Sepsis-3). JAMA. 2016; 315(8): 801-10.

2. Vincent JL, Rello J, Marshall J, Silva E, Anzueto A, Martin CD, et al. International study of the prevalence and outcomes of infection in Intensive Care Units. JAMA. 2009;302(21): 2323-9

3. Sterling SA, Miller WR, Pryor J, Puskarich MA, Jones AE. Impact of timing of antibiotics on outcome in severe sepsis and septic shock: a systematic review and meta-analysis. Crit Care Med. 2015;43(9):1907-15.

4. Dewi RS, Radji M, Andalusia R. Evaluation of antibiotic use among sepsis patients in an Intensive Care Unit. Sultan Qaboos University Med J. 2018; 18(3):367-3.

5. Napotalino LM. Sepsis 2018: Definitions and guideline changes. Surg Infect (Larchmt). 2018;19(2):117-25.

6. Gyawali B, Ramakrisnha K, Dharmoon AS. Sepsis: The evolution in definition, pathophysiology, and management. 
SAGE Open Med. 2019;7: 2050312119835043.

7. Wentowski C, Mewada N, Nielsen ND. Sepsis in 2018: a review. Anasthesia and Intensive Care Medicine. 2018; 20(1):6-12.

8. Levy MM. Evans LE, Rhodes A. The surviving sepsis campaign bundle: 2018 Update. Intensice Care Med. 2018;44(6):925-8.

9. Rukmana RW, Restiana, Nugraheni AY. Evaluasi rasionalitas penggunaan antibiotik pada pasien sepsis di Intensive Care Unit (ICU) RSUD Dr. Moewardi Surakarta Tahun 2016-2017 [Skripsi]. Surakarta: Universitas Muhammadiyah Surakarta; 2018.
10. Kumar A. Optimizing Antimicrobial Therapy in Sepsis and Septic Shock. Crit Care Clin. 2009;25(4):733-51.

11. Tambajong RN, Lalenoh DC, Kumaat $L$. Profil penderita sepsis di ICU RSUP Prof. R. D. Kandou Manado periode Desember 2014-November. e-CliniC. 2016;4(1):452-7.

12. Gul F, Arlantas MK, Cinel I, Kumar A. Changing definitions of sepsis. Turk $\mathbf{J}$ Anaesthesiol Reanim. 2017;24:129-38.

13. O'Toole JA. Sepsis: Immune system meltdown. 2014. Available from: https://www.atrainceu.com/courseall/sepsis-immune-system-meltdown107. 